\title{
Sodium Bicarbonate Cotransporter 3
}

National Cancer Institute

\section{Source}

National Cancer Institute. Sodium Bicarbonate Cotransporter 3. NCI Thesaurus. Code C90141.

Sodium bicarbonate cotransporter $3(1214 \mathrm{aa}, \sim 136 \mathrm{kDa})$ is encoded by the human SLC4A7 gene. This protein is involved in the regulation of intracellular $\mathrm{pH}$. 